\title{
Konsep Kemiskinan Kultural
}

\section{Nur Palikhah}

Fakultas Dakwah dan Komunikasi IAIN Antasari

\begin{abstract}
"Sufficient" worldview for the Javanese community, especially farmers as their values, that is to say they are satisfied, peaceful and calmly with what they get. Javanese peasants working in the fields not for profit, but merely to fulfill the purposes of simple everyday family life. When one shoulder ( $0.7 \mathrm{ha}$ ) of rice fields were planted with a single crop in a year is enough to meet the needs of a family life, then the farmer would not want more than that. What is the meaning and purpose of life if not to achieve peace and inner satisfaction. This view of life such as lack of work ethic is one of the few values or culture that is embraced by the poor due to the culture of poverty where poverty has emerged as a result of the values or culture embraced by the poor.
\end{abstract}

Keywords: poverty, culture, values, worldview.

Pandangan hidup "mencukupi" bagi masyarakat Jawa terutama petani menjadi nilai yang mereka anut, artinya mereka sudah merasa puas, tenteram, dan ayem dengan apa yang mereka dapatkan. Petani Jawa bekerja di sawah bukan untuk mencari keuntungan, tapi sekedar untuk mencukupi keperluan hidup sehari-hari keluarganya yang sederhana. Bila dengan satu bahu (0.7 ha) sawah yang ditanami dengan sekali panen dalam setahun sudah cukup untuk memenuhi keperluan hidup sebuah keluarga, maka sang petani tidak akan menginginkan lebih daripada itu. Apalah arti dan tujuan hidup ini kalau bukan untuk mencapai ketenangan dan kepuasan batin. Pandangan hidup ini seperti kurang memiliki etos kerja merupakan salah satu dari beberapa nilai-nilai atau kebudayaan yang dianut oleh orang miskin yang disebabkan karena adanya kebudayaan kemiskinan dimana kemiskinan muncul sebagai akibat adanya nilai-nilai atau kebudayaan yang dianut oleh orang miskin.

Kata kunci: kemiskinan, kebudayaan, nilai, pandangan hidup.

Konsep kemiskinan kultural pertama kali diperkenalkan oleh Oscar Lewis yang melihat bahwa kemiskinan dapat muncul sebagai akibat nilai-nilai dan kebudayaan yang dianut oleh kaum miskin itu sendiri (Effendi, 1992: 30). Menurut Lewis, kemiskinan tidak hanya dilihat sebagai persoalan ekonomi saja yaitu tidak dikuasainya sumber-sumber produksi dan distribusi benda-benda dan jasa ekonomi oleh orang miskin, tidak juga melihatnya secara makro yaitu dalam kerangka teori ketergantungan antarnegara dan tidak melihatnya sebagai pertentangan kelas. Lewis melihat kemiskinan sebagai cara hidup atau kebudayaan dan unit sasarannya adalah mikro, yaitu keluarga, karena keluarga dilihat sebagai satuan sosial terkecil dan sebagai pranata sosial pendukung kebudayaan kemiskinan (Suparlan, 1988:xviii).

Email penulis: falikhahika@gmail.com

Alhadharah Jurnal Ilmu Dakwah Vol. 15 No. 30, Juli-Desember 2016, 11-27 
Kemiskinan merupakan suatu budaya yang terjadi karena penderitaan ekonomi yang berlangsung cukup lama. Kemiskinan juga sebagai salah satu sub kultur masyarakat yang mempunyai kesamaan ciri antar etnik satu dengan etnik yang lain. Budaya kemiskinan merupakan suatu cara yang dipakai oleh orang miskin untuk beradaptasi dan bereaksi terhadap posisi mereka yang marginal dalam masyarakat yang memiliki kelas-kelas dan bersifat individualistik dan kapitalistik. Budaya kemiskinan sebagai desain kehidupan bagi orang miskin yang berisikan pemecahan bagi problema hidup mereka yang diturunkan dari satu generasi ke generasi selanjutnya (Ancok, 1995:165).

Menurut Portes konsep budaya kemiskinan berusaha untuk menunjukkan situasi tempat masyarakat telah terjerat dalam lingkungan sosial yang ditandai oleh apatis, fatalisme, dan kurang aspiratif dan keprihatinan eksklusif yang terkait dengan kepuasan sepintas dan seringkali membenarkan perilaku kejahatan. Lewis "budaya kemiskinan menunjukkan elemen-elemen budaya yang umum ditemukan di kalangan orang-orang miskin dalam masyarakat yang berbeda". Lewis menekankan pada budaya bawaan yaitu pola-pola perilaku dan nilai-nilai khusus yang dimiliki golongan miskin; pola-pola ini tidak membentuk suatu budaya yang terpisah, tetapi agaknya membentuk variasi budaya nasional sebagai sebuah subbudaya. Sub budaya itu mempunyai sifat-sifat umum yaitu tidak adanya masa kanak-kanak sebagai suatu tahapan daur hidup yang panjang dan terlindungi secara khusus, perkawinan bebas atau bersifat konsensus, keluarga cenderung dikendalikan oleh perempuan yang cenderung otoriter. Lewis menafsirkan sub budaya kemiskinan sebagai suatu reaksi terhadap posisi mereka dalam lapisan kelas, dan dalam masyarakat yang individualis serta kapitalistik (Gilbert, 1996:112).

\section{Kritik Terhadap Budaya Kemiskinan}

Pendapat Lewis mengenai budaya kemiskinan banyak dikritik di mana kritikus itu cenderung melihat bahwa budaya bawaan orang miskin tersebut lebih banyak ditentukan oleh realitas ekonomi dan politik yang sedang mereka hadapi, tekanan struktural. Lewis sendiri kemudian menyatakan "bagaimanapun juga budaya kemiskinan bukan hanya suatu adaptasi terhadap sejumlah kondisi objektif masyarakat yang lebih luas. Sekali budaya kemiskinan itu muncul, maka budaya itu cenderung berlangsung dari generasi ke generasi karena ia berdampak terhadap anak-anak. Anak-anak perkampungan kumuh yang berusia 6 atau 7 tahun biasanya sudah menyerap nilai-nilai dasar dan sikap sub budayanya dan secara psikologis tidak ditopang oleh peluang-peluang demi kehidupan mereka".

Kritik lainnya datang dari beberapa ilmuwan seperti Gans, Baker, Valentine, dan Ignas Kleiden. Dalam konsep budaya kemiskinannya, Lewis menyebutkan bahwa kebudayaanlah yang menyebabkan kemiskinan, jadi kebudayaan sebagai sebab bukannya akibat kemiskinan. Pandangan ini menurut Gans mengandung kelemahan karena konsep kebudayaan seperti itu adalah anti sejarah yang mengesampingkan asal-usul kelakuan dari norma-norma yang ada. Menurut Gans, perilaku dan ciri-ciri yang ditampilkan para kaum miskin adalah merupakan hasil 
interaksi antara faktor kebudayaan yang sudah tertanam di dalam diri orang miskin dan faktor situasi yang menekan. Gans tidak sependapat dengan Lewis yang menyatakan bahwa orang miskin di semua negara itu mempunyai ciri yang sama, menurutnya orang miskin itu bersifat heterogen. Sebagian orang miskin menjadi miskin karena warisan generasi sebelumnya, sedangkan sebagian orang miskin lainnya hanya miskin secara periodik. Gans menolak anggapan bahwa kebudayaan itu bersifat holistik yang elemennya hanya dapat berubah bilamana semua sistem budaya tersebut berubah (Ancok, 1995:167).

Menurut Hans ada yang merasa bahwa kaum miskin juga memeluk nilai-nilai serta aspirasi masyarakat yang berbeda dan andaikata mereka berkesempatan memperoleh pekerjaan yang layak serta sumberdaya lain maka mereka tidak lagi akan menderita akibat-akibat patologik serta kekurangan yang berkaitan dengan keadaan kemiskinan. Menurut Beck lebih banyak ahli sosial berpendapat bahwa orang miskin itu kekurangan. Sedangkan para antropolog mengatakan bahwa kemiskinan serta kedudukan rendah kaum miskin telah mengasilkan terwujudnya kebudayaan masyarakat luar atau kebudayaan kemiskinan yang menghambat kaum miskin untuk dapat menciptakan pola-pola perilaku serta nilai-nilai yang memungkinkan mereka untuk dapat berpartisipasi di dalam masyarakat yang berbeda (Suparlan, 1984:73).

Baker juga mengatakan bahwa konsep kebudayaan kemiskinan itu sangat normatif dan merupakan kumpulan kecurigaan dan prasangka buruk golongan atas terhadap golongan miskin. Selain itu, konsep kemiskinan kultural itu terlalu membesar-besarkan mapannya kemiskinan di mana bukti yang ada menunjukkan bahwa kaum miskin di kota bekerja keras, mempunyai aspirasi tentang kehidupan yang baik dan motivasi untuk memperbaiki nasib. Penduduk miskin di kota secara ekonomi juga terintegrasi dengan masyarakat luas di kota meskipun integrasi itu cenderung menghalangi perkembangan ekonomi mereka yang pada gilirannya memapankan kemiskinan. Jika itu yang terjadi, maka hal ihwal keapatisan mereka tidak semata-mata karena kebudayaan kemiskinan tetapi lebih berkaitan dengan adanya hambatan untuk menorobos sistem ekonomi kota (Effendi, 1992).

Sementara itu, Valentine menolak asumsi Lewis yang menyatakan bahwa ciriciri sub kultur orang miskin sebagai suatu hasil kebudayaan yang turun temurun. Menurutnya ciri-ciri sub kultur orang miskin bukanlah suatu hasil kebudayaan yang turun temurun. Ciri-ciri itu timbul oleh karena situasi yang menekan. Bila situasi yang menekan itu hilang, maka ciri-ciri tersebut akan hilang dengan sendirinya. Situasi yang menekan itu timbul oleh karena struktur total dari sistem sosial yang ada di dalam suatu masyarakat (Ancok, 1995:166). Menurut Kleiden, konsep kebudayaan kemiskinan tidak selalu terdapat di kelompok miskin dan sebaliknya kelompok miskin tidak selalu menerapkan budaya kemiskinan tersebut (Kleiden, 1987:15).

Perspektif kultural mendekati masalah kemiskinan pada tiga tingkat analisis : individual, keluarga, dan masyarakat. Pada tingkat individual, kemiskinan ditandai dengan sifat yang lazim disebut a strong feeling of marginality seperti sikap parokial, 
apatisme, fatalisme, atau pasrah pada nasib, boros, tergantung dan inferior. Pada tingkat keluarga, kemiskinan ditandai dengan jumlah anggota keluarga yang besar dan free union or consensual marriages. Pada tingkat masyarakat, kemiskinan terutama ditunjukkan oleh tidak terintegrasinya kaum miskin dengan institusiinstitusi masyarakat secara efektif. Mereka seringkali memperoleh perlakuan sebagai obyek yang perlu digarap daripada sebagai subjek yang perlu diberi peluang untuk berkembang (Usman, 2004:128)

Budaya kemiskinan oleh Lewis digunakan sebagai suatu model konseptual subkultur masyarakat Barat yang memliki struktur dan dasar pemikiran tersendiri yakni suatu cara hidup yang diwariskan dari generasi ke generasi melalui garis keturunan keluarga. Kebudayaan kemiskinan bukan saja merupakan suatu persoalan deprivasi atau disorganisasi tetapi suatu istilah yang berarti tidak adanya sesuatu hal. Kebudayaan kemiskinan adalah suatu kebudayaan dalam artian antropologi tradisional di mana ia mencerminkan suatu pola kehidupan, serangkaian penyelesaian/solusi yang siap pakai untuk menangani masalahmasalah yang dihadapi oleh manusia, dan karena itu ia menjalankan fungsi adaptasi yang signifikan. Gaya hidup ini terdapat baik pada level nasional, regional, maupun pada bermacam-macam tingkat perbedaan antara desa-kota yang ada dalam negara-negara tersebut. Bila kebudayaan kemiskinan muncul maka mereka yang menganut kebudayaan kemiskinan menunjukkan adannya kesamaankesamaan dalam struktur kebudayaan mereka, dalam hubungan-hubungan interpersonal mereka, dalam kebiasaan berbelanja, dalam sistem-sistem nilai mereka dan dalam orientasi mereka terhadap masa depan (Ala, 1981:17)

Kebudayaan kemiskinan menggambarkan suatu usaha untuk mengatasi rasa putus asa dan tidak berpengharapan dari anggota-anggota masyarakat marginal karena mereka tidak mungkin sukses di dalam mencapai nilai-nilai dan tujuantujuan tersebut terlalu tinggi bagi mereka. Sifat-sifat kebudayaan kemiskinan dapat dilihat dari segi usaha-usaha lokal dan spontanitas untuk memenuhi kebutuhan orang-orang miskin di mana kebutuhan tersebut tidak dapat dipenuhi oleh lembagalembaga dan agen-agen masyarakat yang lebih luas karena orang-orang miskin tersebut tidak memenuhi persyaratan untuk mendapatkan pelayanan dari lembagalembaga tersebut, tidak diperbolehkan, atau mereka bodoh dan mencurigakan (Ala, 1981:20)

Ada tujuhpuluh sifat karakteristik kebudayaan kemiskinan. Salah satu sifat prinsipiil yang memiliki empat aspek yaitu sistem hubungan antara subkultur dengan masyarakat yang lebih luas; sifat kemasyarakatan kaum jembel; sifat keluarga; dan sikap-sikap, nilai-nilai, dan karakter-karakter individual. Dalam kebudayaan kemiskinan, orang-orang miskin tidak mempunyai respek dan tidak terintegrasikan dengan lembaga-lembaga utama yang ada dalam masyarakat. Kebudayaan kemiskinan mencerminkan efek gabungan dari berbagai faktor termasuk kemiskinan, segregasi, diskriminasi, kelatkutan, kecurigaan, dan apathis serta terbentuknya lembaga-lembaga dan prosedur-prosedur alternatif di dalam masyarakat kaum jembel (Ala, 1981:21). 
Masyarakat yang menganut kebudayaan kemiskinan memiliki rasa kehidupan berkelompok yang relatif tinggi, sekurang-kurangnya memiliki suatu organisasi yang melebihi keluarga inti dan keluarga besar. Keluarga-keluarga yang menganut kebudayaan kemiskinan tidak menghargai masa kanak-kanak sebagai suatu bagian yang penting di dalam siklus kehidupan manusia. Terlalu cepat/terlalu awal diadakan inisiasi sex sebelum waktunya. Kawin kontrak menyebabkan keluarga cenderung berpusat pada ibu dan lebih terikat pada keluarga besar pihak ibu. Kepala keluarganya perempuan dan biasanya bersifat otoriter. Individu yang menganut kebudayaan kemiskinan memiliki suatu sifat fatalisme yang kuat, tak berdaya, ketergantungan dan inferior (Ala, 1981:23). Calon-calon yang paling besar kemungkinannya untuk menganut kebudayaan kemiskinan adalah orang-orang yang berasal dari strata yang lebih rendah di dalam masyarakat yang mengalami perubahan dengan pesat dan mereka yang sudah diasingkan dari masyarakat tersebut. Miskin kebudayaan sebagai salah satu sifat dari kebudayaan kemiskinan (Ala, 1981:27)

\section{Bentuk Kemiskinan Kultural}

Kemiskinan kultural dapat ditemukan di beberapa masyarakat Indonesia, masyarakat di kalangan bawah seperti nelayan dan petani. Menurut Lewis, ada polapola kelakuan dan sikap-sikap yang ditunjukkan oleh orang miskin sebagai suatu cara yang paling tepat untuk dapat tetap melangsungkan kehidupan yang serba kekurangan tersebut. Cara hidup ini yang kemudian menjadi landasan bagi terbentuknya kebudayaan kemiskinan yang mereka miliki. Kebudayaan kemiskinan ini kemudian mendorong terwujudnya sikap-sikap menerima nasib, meminta-minta atau mengharapkan bantuan atau sedekah yang sebenarnya merupakan suatu bentuk adaptasi yang rasional dan cukup pandai dalam usaha mengatasi kemiskinan yang mereka hadapi (Suparlan, 1984:21).

Bentuk kemiskinan kultural yang ada dalam buku Oscar Lewis mengenai Kisah Lima Keluarga di Meksiko yang menceritakan mengenai kisah lima keluarga dalam kehidupan sehari-harinya, di mana terdapat pola yang berbeda pada masing-masing keluarga yang berbeda penghasilannya, juga dengan kelas yang berbeda pula. Ada keluarga yang hidup pada taraf hanya untuk menyambung hidup mereka, di mana suami menjadi figur laki-laki yang otoriter dan berkuasa didampingi oleh istrinya yang mendekati sosok ideal sedehana dan patuh, dan anak-anak yang memenuhi syarat-syarat norma-norma pedesaan, keras, hormat, dan patuh, walaupun ketika mereka menjadi semakin tua mereka mulai berubah sebagai tanggapan terhadap perubahan dari luar. Ada keluarga yang hidup di kota di mana anak-anak mereka membantu penghidupan keluarga, kehidupan beragama menjadi lebih penting, sistem ayah angkat atau wali masih berfungsi, mereka masih mempertahankan sanak keluarga mereka yang di desa dan mempertahankan kepercayaan dan adat kebiasaan, tetapi ada perubahan yang sangat mencolok di mana ibu menjadi tokoh yang dominan dalam suatu keluarga, kebebasan yang lebih besar bagi anakanaknya, standar kehidupan yang terus meningkat dengan pembelian barang- 
barang yang dicicil. Ada keluarga yang termiskin di kota itu, di mana anak-anak mereka tidak mendapatkan pendidikan yang jauh lebih baik dari orang tua mereka. Istri mempuyai pengaruh yang sangat besar dan mereka menggunakannya walaupun bahkan mereka masih menunjukkan sikap patuh kepada suami. Dalam menilai hubungan antara orang tua dan anak-anak dalam lima keluarga tersebut, anak-anak mempunyai hubungan emosional yang lebih erat dengan ibu mereka, semua anak menghormati ayah mereka dan mempunyai rasa kasih sayang, semua ibu mengabdi, mengorbankan diri, dan sangat berorientasi pada anak. Ayah lebih otoriter, kurang beroreintasi pada anak dan menghabiskan banyak waktunya di luar rumah. Generasi muda dalam kisah lima kaluarga ini menikmati stabilitas keluarga yang lebih besar dan masa kanak-kanak yang lebih lama dibandingkan dengan yang dialami oleh orangtua mereka.

Bentuk kemiskinan kultural dapat dilihat dari ciri-ciri yang ada di dalamnya. Ada beberapa ciri kebudayaan kemiskinan Lewis dan Harrington pada beberapa tingkat yaitu pada tingkat individu tampak bahwa orang yang hidup dalam kebudayaan kemiskinan praktis tidak mengalami masa kecil atau mengalami masa kecil yang sangat singkat, dikarenakan anak-anak dalam keluarga tersebut sudah terpaksa bekerja terlalu dini untuk memenuhi kebutuhan keluarga dan karena hubungan seksual yang sangat terbuka dan permisif dalam kelompok ini menyebabkan anak-anak matang secara seksual lebih cepat dari umurnya. Pada tingkat keluarga kelihatan bahwa keluarga tidak mempunyai pola yang tetap di mana kegiatan dilakukan karena dorongan atau kebutuhan yang datang sewaktuwaktu (impulse determined), demikian juga dalam nafkah justru mengandalkan peranan wanita (female based) karena kaum laki-laki mempunyai kecenderungan yang sangat kuat kepada tindakan kekerasan (action-seeking). Pada tingkat sosial dan lembaga sosial kelihatan bahwa orang yang dihinggapi kebudayaan kemiskinan mempunyai kemampuan integrasi sosial yang sangat rendah dengan akibat bahwa rasa identitasnya pun lemah, hubungan sosial penuh dengan sikap curiga, dan kemampuan yang rendah dalam menerima dan mentolerir kekecewaan. Pada tingkat mentalitas ada beberapa sifat-sifat umum yaitu kemampuan bahasa yang terlambat, kesulitan menunda kesenangan, dan ketidakmampuan dalam berfikir konseptual dan kecenderungan yang sangat kuat dalam menggunakan reaksi motorik dalam mengatasi kekecewaan dan kegagalan. Pola-pola tersebut kemudian diwariskan secara turun-temurun (personality of poverty) (Kleiden, 1987:15).

Sementara itu ciri pokok orang yang hidup dengan budaya miskin adalah kurangnya partisipasi yang efektif dan integratif dalam institusi-institusi penting yang ada dalam masyarakat, karena sebagian besar yang buta huruf dan berpendidikan rendah serta kekurangan uang. Orang yang hidup dalam budaya kemiskinan mempunyai ciri kepribadian yaitu merasa diri mereka tidak berguna, penuh dengan keputusasaan, merasa inferior, sangat dependen pada orang lain, kurang bisa mengontrol diri, mudah impulsif, sangat berorientasi pada masa kini tanpa memikirkan masa depan. Sifat-sifat tersebut dapat digunakan sebagai cara untuk beradaptasi terhadap tekanan kehidupan juga merupakan belenggu yang 
menyulitkan orang miskin untuk lepas dari tekanan kehidupan tersebut (Ancok, 1995:165).

\section{Penyebab Kemiskinan Kultural}

Kebudayaan menjadi penyebab dalam kemiskinan kultural yaitu berupa nilainilai, tradisi-tradisi yang dikembangkan secara kultural, dan pandangan hidup yang berkembang di antara mereka. Ada pola-pola kelakuan dan sikap-sikap yang ditunjukkan oleh orang miskin sebagai suatu cara yang paling tepat untuk dapat tetap melangsungkan kehidupan yang serba kekurangan. Cara hidup ini yang kemudian menjadi landasan bagi terbentuknya kebudayaan kemiskinan yang mereka miliki. Misalnya saja nelayan telah dikenal sebagai salah satu kelompok masyarakat dengan tingkat pendapatan yang sangat minim, di mana hasil tangkapan mereka hanya cukup untuk menyambung hidup dari hari ke hari saja, tidak lebih dari itu. Akan tetapi, dengan penghasilan yang sedikit itupun mereka masih melakukan tradisi mereka yang selalu berfoya-foya selepas melaut. Menurut DJ Pamoedji, seorang wartawan senior yang puluhan tahun berkecimpung di pelabuhan dan nelayan, mengatakan, nelayan memiliki tradisi berfoya-foya karena mungkin menjadi sarana melepas tekanan kehidupan di laut. Sebaliknya, mekanisme hidup yang ada hanya menjerat mereka pada kesenangan sesaat dan selalu tergantung pada utang (Husain,2006). Jeratan utang seumur hidup akan menjerat para nelayan meski hasil melaut yang mereka dapat bertambah. Otomatis pengeluaran mereka selalu bertambah karena kebiasaan tidak mampu mengelola uang dan menabung. "Warung minuman keras dan tempat hiburan malam bisa dipastikan hadir di setiap perkampungan nelayan. Selesai melaut uang biasanya habis di tempat hiburan. Untuk menyambung hidup selalu berutang pada tengkulak," kata Pamoedji. Hal ini menunjukkan bahwa kebiasaan mereka seharihari telah membawa mereka masuk ke dalam jurang kemiskinan. Dari gambaran ini, kemiskinan kultural sebagai salah satu bentuk kemiskinan yang disebabkan oleh adat, budaya, ataupun sifat dari pada anggota masyarakat yang membuat mereka menjadi miskin. Kebiasaan itu terus berlanjut sehingga menghasilkan suatu proses pemiskinan yang terus berlanjut di mana selama budaya kemiskinan itu ada di tengah-tengah masyarakat maka kemiskinan itupun tidak akan beranjak dari kehidupan mereka.

Pandangan hidup, nilai-nilai yang berlaku dalam suatu masyarakat mendorong terwujudnya kemiskinan kultural ini. Masyarakat Jawa sebagai salah satu masyarakat yang memegang teguh nilai-nilai dan pandangan hidup mereka menunjukkan bahwa kemiskinan itu tetap lestari dalam kehidupan mereka dikarenakan nilai-nilai yang masih mereka anut. Petani Jawa misalnya, mereka bekerja di sawah bukan untuk mencari keuntungan, tapi sekedar untuk mencukupi keperluan hidup sehari-hari keluarganya yang sederhana. Bila dengan satu bahu (0.7 ha) sawah yang ditanami dengan sekali panen dalam setahun sudah cukup untuk memenuhi keperluan hidup sebuah keluarga, maka sang petani tidak akan menginginkan lebih daripada itu. Dia sudah merasa puas, tenteram, dan ayem. 
Apalah arti dan tujuan hidup ini kalau bukan untuk mencapai ketenangan dan kepuasan batin. Dari ilustrasi ini terlihat bahwa dalam masyarakat Jawa berkembang nilai-nilai bahwa dunia materi itu tidak baik. Bagi orang Jawa, mengejar harta dan keuntungan materi, sama seperti "minum air laut : makin diminum makin haus". Nilai dan sikap seperti ini tidak sepantasnya dianut oleh orang Jawa yang bijaksana karena bagi mereka tujuan hidup itu untuk mencapai ketenangan dan kepuasan batin (Marzali, 2003:10).

Pandangan hidup, nilai-nilai, dan tradisi yang dikembangkan oleh masyarakat Jawa tersebut dianggap menghambat. S.H Alatas dengan bukunya "The Myth of the Lazy Native" mengungkapkan mengenai alasan-alasan yang digunakan imperialisme dan kolonialisme Barat untuk menjajah bangsa-bangsa Asia Tenggara. Dengan bahasa yang sangat menghina terhadap orang-orang Melayu, Jawa dan Filipina, para penulis kolonial menciptakan mitos tentang kemalasan para pribumi, yang membuat mereka merasa berhak untuk menjajah dan menguras kekayaan bangsa lain selama berabad-abad. Padahal semua pribumi yang dimaksud adalah pekerja keras, namun tidak mau diperbudak imperialis dan kolonialis, lalu penolakan tersebut dimanipulasi sebagai kemalasan (Bali Post.htm).

Kemalasan menjadi alasan bagi masyarakat pribumi menjalani segala kehidupan. Menurut Irwan Abdullah, ciri internal kelompok masyarakat Indonesia memang sejak masa kolonial telah dinilai sebagai penghambat proses modernisasi. Pandangan yang mengatakan bahwa kaum pribumi merupakan kelompok masyarakat yang malas telah menjadi mitos di dalam menjelaskan berbagai bidang kehidupan. Tidak hanya dalam masyarakat Indonesia mentalitas dianggap penting di dalam berbagai proses perubahan. Di banyak masyarakat dunia ketiga, hal serupa juga dapat ditemukan. Di masyarakat India, mentalitas tradisional dinilai sebagai penghambat utama proses pembangunan terutama menyangkut aspirasi yang terbatas di dalam penerimaan ide-ide dan praktik-praktik kehidupan yang lebih modern (Abdullah, 2002).

Mitos pribumi malas sebenarnya kurang pas jika dilabelkan untuk masyarakat Indonesia, yang terjadi sesungguhnya adalah masyarakat Indonesia belum siap menghadapi tantangan jaman, di mana secara umum tingkat pengetahuan masyarakat Indonesia masih rendah, etos kerja yang rendah pula sehingga kapasitas yang mereka miliki tidaklah memadai. Sebagai contoh, menurut KuntjoroJakti (1986) kaum miskin sebagian besar mampu menciptakan lapangan kerja sendiri serta bekerja keras untuk memenuhi tuntutan kehidupan mereka.

Penyebab kemiskinan dari sudut budaya di mana penjelasan mengapa miskin itu tidak dicari dari luar melainkan dicari dari dalam diri orang atau masyarakat miskin itu sendiri sebagai pihak yang tertuduh sebagai penyebabnya. Penjelasan ini diangkat dari perspektif kalangan konservatif di mana orang menjadi miskin karena jebakan budayanya sendiri yang kemudian diwariskan secara turun temurun. Individu-individu yang ada dalam masyarakat dianggap terjebak pada kebiasaankebiasaan hidup berikut nilai-nilai sosial dalam masyarakat di mana ia ataupun mereka itu berada. Budaya hidup miskin dianggap sebagai produk sosial kolektif 
yang pada akhirnya dipandang sebagai kekuatan eksternal yang koersif (memaksa) di mana individu larut atau tidak berdaya di dalamnya, karena memang tidak mempunyai kekuatan untuk melawannya. Watak malas, orientasi hidup yang hanya berdasarkan kebutuhan pragmatid sehari-hari atau tidak berorientasi ke depan, kemanjaan terhadap lingkungan akibat suburnya lahan sehingga merasa tak perlu kerja keras karena memang sumber penghidupan dapat dengan mudak diperoleh; merupakan sebagian dari faktor-faktor yang kemudian membentuk budaya dan lalu menjebak mereka dalam kondisi hidup miskin (Darwin, 2005).

Menurut Lewis, akar dari budaya miskin adalah keadaan masyarakat yang mempunyai ciri-ciri sebagai berikut:

a. Sistem perekonomian yang terlalu berorientasi pada mencari keuntungan

b. Tingginya angka pengangguran dan angka 'underemployment' bagi golongan yang tidak mempunyai keahlian

c. Rendahnya upah/gaji yang diperoleh para pekerja

d. Tidak adanya organisasi sosial, politik, dan ekonomi bagi kaum miskin baik yang didirikan oleh pemerintah maupun oleh swadaya masyarakat

e. Hadirnya sistem kekeluargaan yang bilateral yang menggantikan sistem yang unilateral

f. Hadirnya kelas masyarakat yang dominan, yang menekankan pada penumpukan harta dan kekayaan, kesempatan untuk terus meningkat dalam status (upward mobility). Anggota kelas masyarakat ini beranggapan bahwa kemiskinan disebabkan oleh karena sifat pribadi yang lemah dan inferior.

Pemerintah juga turut menyebabkan kemiskinan kultural itu tumbuh subur di mana kemiskinan sosial-budaya diciptakan sendiri oleh pemerintah ketika krisis 1997-1999 terjadi (Sukamdi, 2003). Pemerintah membuat program jaring pengaman sosial (Social Security Net) yang tujuannya semula untuk membantu orang-orang miskin. Akan tetapi ternyata bantuan itu malah membuat mereka menjadi tergantung, dan memunculkan kondisi bahwa 'poor was a blessing, because by being poor, they could receive money. If they were not poor, they had to work hard to convince others that they were poor'. Kalau menengok sebelumnya, masyarakat di pedesaan adalah masyarakat yang tidak merasakan dampak dari krisis tersebut, karena sebelum krisis pun mereka juga sudah miskin, jadi krisis dianggap sebagai sesuatu yang normal, sebagai bagain dari dinamika kehidupan yang memang tidak bisa mereka hindari. Pasrah dan nrimo menjadi jalan keluar dari krisis tersebut, karena dengan 'pasrah' dan 'nrimo' dan mendekatkan diri kepada Tuhan maka mereka telah mendapatkan rasa aman (nrimo has a very deep meaning. It is related to observing and understanding whatever is happening. People with nrimo culture will always be happy with whatever they have). Program pemerintah (SSN) memberi kesan bahwa "menjadi miskin itu merupakan kondisi di mana orang lain itu harus turut membantu" being poor was a state where other people should help. The poor was defined as they needy who sould receive charity. Pemerintah seakan-akan mendidik mereka untuk malas dengan memberikan insentif. Oleh karena itu, program pemerintah telah menciptakan suatu kondisi ketergantungan dan juga mematikan 
kreativitas orang-orang itu (mereka merasa bahwa karena mereka miskin maka mereka berhak mendapatkan bantuan baik dari pemerintah ataupun dari sektor lainnya). Menurut Kleiden pemerintah mempunyai andil yang besar dalam memperkenalkan kemiskinan sosial-budaya melalui implementasi program SSN. Intervensi dari pemerintah telah meningkatkan marginalisasi dan keterisolasian rumah tangga miskin, dengan bantuan pemerintah pun mereka berada di posisi yang termarginalkan. Government has actually introduced a feeling of sosial culture poverty by implementing the SSN programme, with aid which does not respond to their aspirations, they have basically become subordinated to a lower position.

\section{Dampak Kemiskinan Kultural}

Konsep kemiskinan kultural menunjukkan bahwa golongan miskin itu menjadi miskin karena mereka memang miskin. Anak-anak makan tak layak, menerima pendidikan yang minim, dan menerima anggapan keluarga atau teman sejawat bahwa kemiskinan itu sebagai suatu keniscayaan. Hal ini menimbulkan anggapan bahwa kemiskinan sebagai suatu keniscayaan maka ada perbuatan-perbuatan yang melanggar peraturan menjadi sesuatu yang wajar terjadi. Dampaknya kemudian adalah munculnya kriminalitas dan kekerasan yang selalu menyertai kehidupan mereka sehari-hari, juga memunculkan kondisi kemiskinan bersama. Lewis menyimpulkan bahwa keadaan yang serba menyimpang itu berakar dari kondisi lingkungan yang serba miskin yang cenderung diturunkan dari generasi ke generasi. Dengan kata lain, kaum miskin telah memasyarakatkan nilai-nilai dan perilaku kemiskinan, akibatnya perilaku tersebut melanggengkan kemiskinan mereka. Tindakan kekerasan dan kriminal itu terjadi karena adanya ketidakmampuan mereka dalam berfikir konseptual dan kecenderungan yang sangat kuat dalam menggunakan reaksi motorik dalam mengatasi kekecewaan dan kegagalan (Kleiden, 1987:16).

Kekerasan merupakan perilaku sosial yang menjadi produk dan stimulan perilaku-perilaku seseorang terhadap orang lain. kekerasan merupakan bentuk respon yang berstruktur dan lahir dari endapan berbagai pengalaman yang tidak memuaskan. Ilegalitas kekerasan sebagai salah satu dampak dari kemiskinan kultural ini terjadi karena orang miskin kecenderungannya bependidikan rendah. Oleh karena itu mereka selalu kalah bersaing ketika ada kompetisi untuk mengisi kesempatan kerja ataupun berkompetisi dalam bidang yang lain, bahkan mereka kadang kalah sebelum bertanding. Ada semacam kesenjangan sosial yang melanda kehidupan orang miskin. Ketika kesenjangan sosial itu dapat diterima oleh masyarakat miskin sebagai suratan nasib yang tidak perlu disesali atau masih berada dalam ambang batas toleransi ,maka kesenjangan itu bukanlah suatu masalah. Akan tetapi ketika kesenjangan itu mulai dilihat dan dipahami sebagai eksploitasi atau dianggap sudah berada di luar ambang batas toleransinya, maka amat potensial menimbulkan kekerasan (Usman, 2004:141)

Budaya kemiskinan telah menelurkan tindakan-tindakan kekerasan yang dianggap sebagai sesuatu yang sah. Kekerasan menjadi makanan mereka sehari- 
hari, di mana tampak bahwa kemiskinan itu memaksa mereka melakukan tindakan kriminalitas. Sebagai ilustrasinya adalah orang miskin di perempatan lampu merah, mereka beroperasi setiap hari dengan pola yang sama. Mendekati mobil ketika lampu merah menyala dengan menengadahkan tangannya untuk meminta-minta, sambil membawa peralatan 'kerja' mereka ditambah juga benda logam yang runcing (seng) yang akan dipergunakan ketika kondisi mereka 'terjebak'. Ketika mereka tidak mendapatkan apa yang mereka minta, muncul seliweran pikiran bahwa mereka harus makan hari itu, sedangkan uangpun tak ada. Kondisi ini menyebabkan mereka tertekan dan tanpa berfikir panjang mereka pun melakukan tindakan kekerasan. Tak ada kompromi dalam hidup mereka, hanya sebatas keinginan menyambung hidup hari itu juga tanpa disertai motivasi lainnya.

Banyaknya kebutuhan hidup yang harus mereka penuhi, dengan waktu yang cukup mendesak, dengan pendidikan mereka yang rendah, akan sangat cukup membuat mereka berhak melakukan tindakan kekerasan. Tak ada kompromi apakah itu melanggar hukum, norma, ataupun telah merugikan orang lain. Seakanakan mereka memang dibolehkan untuk melakukan itu semua karena mereka miskin. Seakan-akan ada toleransi yang cukup besar bagi orang miskin ketika mereka melakukan tindakan kekerasan. Sepertinya pola pikir yang ada menunjukkan bahwa 'yang orang miskin lakukan itu benar' dan yang lainnya 'harap maklum karena mereka itu miskin'. Tanpa disadari sebenarnya kita pun sering mengiyakan pola pikir seperti ini. Ketika orang meminta-minta di lampu merah, di otak kita sudah terpola bahwa orang minta-minta itu miskin dan kita pun sering turut mengakui bahwa karena mereka miskin maka mereka boleh meminta-minta. Padahal ada satu kasus yang menunjukkan bahwa satu desa itu seluruh warganya berprofesi sebagai peminta-minta. Mereka adalah orang yang kaya, akan tetapi karena kebiasaan mereka meminta tanpa butuh kerja keras sudah mendatangkan hasil yang cukup besar maka mereka pun menggeluti profesi itu. Dari ilustrasi ini, terlihat bahwa ada pola-pola yang sudah membekas di pikiran kita bahwa 'maklum karena dia miskin' yang menyebabkan budaya kemiskinan itu tetap tumbuh subur. Pemakluman-pemakluman dan tolerasi-tolerasi yang ada menyebabkan tindakan kekerasan dan kriminal tetap langgeng di sebuah masyarakat.

Selain ilegalitas kekerasan, budaya kemiskinan juga memunculkan kemiskinan bersama (shared poverty). Konsep kemiskinan bersama yang didengungkan oleh Geertz hanyalah sebagai konsekuensi belaka dari involusi usaha tani : tingkat produktivitas yang tidak menaik (atau bahkan turun) mendorong pembagian rezeki kepada pembagian tingkat nafkah yang rendah bagi semua. Geertz membalikkan kesimpulan Boeke dengan menyatakan bahwa "masyarakat Jawa telah menjadi miskin oleh penjajahan maka karena itu statis"(Geertz, 1981).Konsep "shared poverty" yang dikemukakan Geertz sesungguhnya dapat dibaca sebagai 'kebersamaan' suatu keluarga luas dalam menghadapi tekanan penduduk dan keterbatasan lahan pertanian di Jawa. Pada tingkat komunitas, konsep ini dapat dilihat sebagai kuatnya "komunalisme" dalam masyarakat yang membagi rata beban kebutuhan sember penghasilan (Abdullah, 1998:9). 
Kemiskinan bersama menjadi salah satu dampak dari kemiskinan kultural. Ilustrasi berbagi kemiskinan dengan supir angkut di daerah Cikalong misalnya untuk angkutan pedesaan yang beroperasi dari jam 5 pagi sampai jam 9 malam, setiap 15 menit di pagi hari dan makin jarang pada malam hari. Satu kali trip yang berjarak $17 \mathrm{~km}$ yaitu mulai dari terminal bis Muka di Cianjur sampai Pasar Baru kota Cikalong mengambil waktu 35 menit, dengan ongkos Rp 400,00 pada tahun 1989-1990. Jumlah angkut ini dirasakan melebihi kebutuhan penduduk sehingga menimbulkan persaingan yang tidak sehat antara sesama mereka. Menurut hukum lalu lintas, sebagaimana yang tercetak di kedua dinding mobil angkut, kendaraan ini hanya boleh dimuati oleh 10 penumpang termasuk supir dengan $90 \mathrm{~kg}$ barang. Tapi dalam kenyataannya hukum ini tidak pernah ditaati, karena supir angkut mempunyai hukumnya sendiri, yaitu 2 penumpang dan seorang supir di bangku depan, 4 penumpang di bangku belakang kiri, 6 penumpang di bangku belakang kanan, 2 penumpang berkicik-kicik di atas jongkok darurat di punggung supir, dan terakhir 1 lagi adalah kenek yang bergelayut di pintu belakang, sehingga genap semua penumpang menjadi 16 penumpang. Inilah keadaan yang normal. Dalam keadaan lain, angkut ini bisa membawa 17 penumpang dewasa, 3 anak-anak, dan 1 orang bayi, ditambah dengan sejumlah barang di dalam dan di atas atap kendaraan, sehingga tidak menyisakan ruang bagi kaki penumpang untuk bernafas. Inilah salah satu bentuk berbagi kemiskinan antara pihak supir dengan penumpang (Marzali, 2003:31).

Dari kondisi tersebut, terdapat pemakluman-pemakluman yang sangat membahayakan jiwa semua penumpang termasuk sopir dan penumpangnya. Kemiskinan menyebabkan mereka nekat melakukan apa saja, meskipun mereka tidak secara langsung menyadarinya. Di satu sisi sopir angkot membuat aturan hukum sendiri dengan alasan 'biar dapur tetap ngebul', di sisi lain penumpang merasa bahwa keadaan seperti itu adalah pengorbanan dan bahaya. Hampir sama kasusnya dengan ilegalitas kekerasan, di mana dalam hal ini adalah ilegalitas pelanggaran peraturan. Sepertinya penumpang pun merasa bahwa kondisi seperti itu telah lumrah dan mereka pun memberi toleransi terhadap fenomena seperti itu. Sama-sama menganggap persoalan yang tidak biasa itu menjadi biasa bagi orang miskin. Menganggap bahwa melanggar peraturan itu wajar bagi orang miskin. Bagi orang miskin sepertinya kondisi tersebut memang mengharuskan mereka menerima ketidakwajaran tersebut.

Kekerasan sebagai salah satu dampak dari kemiskinan kultural dikarenakan ada kecemburuan sosial dalam kehidupan masyarakat. Ada masyarakat yang karena kesempatan terbuka luas baginya berhasil dan sukses memperoleh kekayaan yang lebih dari yang lain, sedangkan yang lainnya tidak memperoleh kesempatan apapun dalam mengembangkan dirinya. Hal ini menimbulkan jurang kesenjangan sosial yang terbuka lebar antara yang miskin dan yang kaya. Menurut George M.Foster dalam tulisannya Peasant Society and the Image of Limited Good (1965) mengatakan bahwa di dalam masyarakat terutama masyarakat pedesaan terdapat gagasan yang melekat pada sistem gagasan warga pedesaan, bahwa segala sesuatu yang ada 
dalam kehidupan masyarakat itu jumlahnya terbatas, apakah itu berbentuk benda atau kekuasaan. Oleh karena itu, mereka yang kehidupannya lebih baik dari ratarata penduduk, dalam alam pikiran masyarakat sebenarnya telah mengambil sebagian dari milik bersama itu untuk kepentingan dirinya sendiri. Oleh karena itu untuk menjaga stabilitas kehidupan masyarakat, mereka yang telah mengambil milik masyarakat yang terbatas itu dengan secara berlebihan diharapkan dapat mengembalikannya kepada masyarakat dalam berbagai bentuk transaksi sosial, baik dalam berbagai persoalan yang muncul dalam masyarakat. Kecemburuan dalam masyarakat muncul karena masyarakat memandang bahwa hak bersama telah diambil oleh sejumlah kecil masyarakat, hanya untuk kepentingan diri mereka sendiri. Ada semacam tindakan simbolik dari mayoritas masyarakat yang seolah mengatakan bahwa "kamipun berhak atas kesuksesan yang telah anda capai" (Sairin, 1997:72).

Berbagai tindakan kekerasan menyadarkan kita bahwa nilai-nilai kemanusiaan yang diyakini sebagai unsur pendukung utama dalam membentuk kualitas sumber daya manusia tidak lagi menjadi pegangan dalam tatanan kehidupan, harkat, dan martabat manusia. Tindak kekerasan sering terjadi pada masyarakat miskin karena kondisi lingkungan yang buruk seperti ruang sempit, penuh sesak, tidak ada sekat, dan kotor yang dapat memicul emosional seseorang sehingga memberikan peluang melakukan tindak kekerasan. Perilaku kekerasan muncul karena ekspresi tidak berdaya dalam menghadapi masalah hidup (frustasi) dan adanya beban sebagai tanggung jawab mereka (Aminatun, 2003:71).

\section{Pilihan Kebijakan}

Pilihan kebijakan yang berkaitan dengan kemiskinan kultural di antaranya yaitu:

Membuat gerakan bagi orang miskin. Untuk menghilangkan budaya kemiskinan, Lewis menyarankan agar orang-orang miskin bersatu dalam suatu organisasi. Menurut Lewis, setiap gerakan baik itu gerakan bersifat religius, pasifis, ataupun revolusioner yang mengorganisasikan dan memberikan harapan bagi si miskin dan secara efektif mempromosikan solidaritas dan perasaan identitas yang sama dengan kelompok masyarakat yang lebih luas, akan dapat menghancurkan sifat-sifat utama yang merupakan ciri orang-orang dari budaya kemiskinan (Ancok, 1995:166).

Melakuan perubahan yang simultan dalam beberapa hal. Kebijakan menurut Valentine untuk merubah keadaan orang-orang miskin ke arah yang lebih baik harus diadakan perubahan yang simultan dalam tiga hal yaitu : penambahan resources (kesempatan kerja, pendidikan, dll) bagi orang miskin. Kedua perubahan struktur sosial masyarakat dan ketiga perubahan-perubahan di dalam sub kultur masyarakat orang miskin tersebut. Sumber perubahan yang paling mungkin adalah gerakan-gerakan sosial untuk menghidupkan kembali keyakinan diri kelompok miskin. Gerakan ini berasal dari dalam kelompok orang miskin tersebut. Bila timbul keyakinan diri tersebut, maka hambatan-hambatan kultural yang merupakan ciri masyarakat miskin akan terkikis (Ancok, 1995:166). 
Perluasan kesempatan bagi orang miskin. Menurut Gans pemecahan terakhir adalah kemiskinan terletak pada usaha untuk mengetahui faktor-faktor yang menghambat orang miskin untuk menggunakan kesempatan yang tersedia, dan usaha untuk memberikan keyakinan diri pada si miskin untuk menggunakan kesempatan yang tersedia walaupun kesempatan yang tersedia tersebuit bertentangan dengan nilai-nili kebudayaan yang dianut saat itu. Untuk menyediakan kesempatan tersebut diperlukan pemehaman tentang perubahan yang diperlukan dalam sistem ekonomi, struktur kekuasaan, dan norma-norma serta aspirasi kelompok orang kaya yan ikut memungkinkan timbulnya kelompok orang miskin (Ancok, 1995:167).

Pemberdayaan yang sebesar-besarnya bagi orang miskin. Peluang untuk sukses dalam mengentaskan kemiskinan akan lebih besar bila kaum miskin diberi peluang yang lebih besar untuk mengurus dirinya sendiri, mempengaruhi keputusan, dan berpartisipasi dalam kegiatan yang mempengaruhi kemampuan ekonomi dan kesejahteraan hidup. Peranan pihak pemerintah sejauh mungkin dibatasi pada upaya merealisasikan kehendak masyarakat, penyediaan dana dan prasarana. Keterlibatan masyarakat dalam mengurusi diri sendiri akan menjadi penopang keberhasilan pengentasan kemiskinan karena akan menjadi menumbuhkan perasaan bangga atas kemampuan diri sendiri. Pemerintah perlu mengurangi secara gradual keterlibatannya di dalam penentuan jenis kebijakan yang harus diambil.

Peninjauan kembali rumusan kebijakan mengurangi kemiskinan. Asumsi dasar dalam merumuskan kebijakan memerangi kemiskinan perlu ditinjau kembali. Kebijakan yang diterapkan sebaiknya mengacu pada kebijakan menciptakan peluang kerja yang lebih produktif; tekanan pada produktif ketimbang pekerjaan. Asumsi dasar yang mengacu pada konsep sektor informal salah satu alternatif yang eprlu dipikirkan. Konsep ini memusatkan perhatian pada usaha yang lebih menekankan pada kebijakan yang merangsang pertumbuhan ekonomi. Tindakan yang memusuhi kegiatan sektor informal perlu dihindari. Kegiatan sektor informal perlu ditingkatkan melalui usaha-usaha pembinaan dalam bidang ketatalksanaan dan teknik pemasaran. Lembaga swadaya masyarakat perlu disertakan dalam pengembangan usaha kegiatan sektor informal yang kebanyakan dilakukan oleh penduduk miskin di kota, dapat ditingkatkan yang secara tidak langsung dapat membuka peluang dan pilihan-pilihan baru bagi penduduk miskin kota (Effendi, 1992: 32).

Melakukan perubahan dalam pola sosialisasi anak-anak miskin. Menurut Lewis, anak-anak perkampungan kumuh yang berusia 6-7 tahun biasanya sudah menyerap nilai-nilai dasar dan sikap sub-budayanya dan secara psikologis tidak ditopang oleh peluag-peluang demi kehidupan mereka. Lewis menggunakan determinasi masa awal anak-anak yang berarti sekaligus menyatakan bahwa gerakan apapun yang dapat memberikan harapan kepada golongan miskin secara efektif akan mendorong solidaritas dan identifikasi terhadap kelompok-kelompok yang lebih besar yang berarti akan menghancurkan inti budaya kemiskinan baik 
secara psikologis maupun sosial (Gilbert, 1996:178). Kelakuan terwujud sebagai hasil dan adaptasi terhadap situasi yang dihadapi Sebagian besar dari kelakuan tidak lebih daripada suatu respon yang berlaku bagi situasi tertentu yang dihadapi dan hal itu adalah sebab adanya situasi yang bersangkutan. Pola-pola kelakuan yang lain menjadi norma kelakuan yang dijadikan pegangan.

Meningkatkan etos kerja kelompok miskin. Strategi untuk meningkatkan etos kerja kelompok miskin adalah dengan meningkatkan pendidikan. Apabila mereka berpendidikan maka mereka akan mempunyai pola pikir yang lebih maju sehingga mereka mampu mempunyai pola pikir yang melihat masa depan. Selain itu mereka juga akan mampu menata kembali institusi-institusi ekonomi kita supaya dapat mewadahi kebutuhan serta aspirasi kelompok miskin (Usman, 2004:129).

Mengadakan perubahan struktur-struktur yang ada dalam masyarakat. Mengadakan perubahan struktur-struktur yang ada dalam masyarakat secara mendasar; mengadakan redistribusi kekayaan; mengorganisir orang-orang miskin dan menimbulkan sense of belonging; memberikan kekuasaan dan kepemimpinan; revolusi-revolusi seringkali berhasil menghapuskan beberapa karakteristik dasar kebudayaan kemiskinan walaupun revolusi tersebut bisa tidak berhasil mengobati kemiskinan itu sendiri (Ala, 1981:30).

\section{Kesimpulan}

Kebudayaan telah membuat kemiskinan itu tetap lestari dalam kehidupan mereka. Adanya pandangan hidup ataupun nilai-nilai yang mereka pegang turut mendorong mereka terpuruk dalam kemiskinan. Kemiskinan ini lebih disebabkan oleh kebudayaan, di mana kemiskinan tidak disebabkan oleh keterbatasan akses ekonomi akan tetapi lebih disebabkan karena nilai-nilai, pandangan hidup, dan norma-norma yang berkembang di dalam suatu masyarakat. Kemiskinan itu muncul dari dalam diri orang miskin itu sendiri. Kebiasaan ini telah menyebabkan mereka terjebak dalam kemiskinan.

Kekerasan menjadi dampak yang jelas terlihat dari kemiskinan kultural ini. Sering digunakannya kekerasan telah memberikan suatu kemungkinan bagi mereka yang berkebudayaan kemiskinan untuk mengatasi berbagai tindakan kekerasan. Kekerasan digunakan sebagai jalan keluar dan seolah-olah tindakan itu adalah tindakan yang sah mereka lakukan. Semua itu didasarkan karena mereka miskin sehingga boleh saja melakukan tindakan kekerasan. Kondisi ini disebabkan karena kaum miskin telah memasyarakatkan nilai-nilai dan perilaku kemiskinan, akibatnya perilaku tersebut melanggengkan kemiskinan mereka. Tindakan kekerasan dan kriminal itu pun terjadi karena adanya ketidakmampuan mereka dalam berfikir konseptual dan kecenderungan yang sangat kuat dalam menggunakan reaksi motorik dalam mengatasi kekecewaan dan kegagalan. Akumulasi darikegagalan dan kekecewaan tersebut menyebabkan mereka tidak mampu lagi untuk berkompromi mengenai apakah tindakan yang mereka lakukan benar atau salah. 
Pilihan kebijakan yang dapat membuat orang miskin bangkit dari kemiskinannya adalah dengan pemberdayaan orang miskin sehingga ia akan merasa berguna baik bagi dirinya sendiri ataupun bagi orang lain. Dengan kepercayaan diri yang mereka miliki itu, diharapkan mereka dapat melakukan gerakan-gerakan yang dapat membuat mereka mampu melakukan berbagai hal. Perubahan sosialisasi anakanak miskin, perluasan kesempatan bagi mereka,dan kepercayaan diri mereka bahwa mereka mampu membuat suatu perubahan maka hambatan-hambatan kultural yang merupakan ciri masyarakat miskin akan terkikis.

\section{Referensi}

Abdullah, Irwan. 1998. "Sosial Security dari Solidaritas Mekanis ke Formalisasi Mekanisme Sosial” dalam Seminar Social Security and Sosial Policy, Yogyakarta 28-29 Desember 1998. Pusat Studi Kependudukan UGM : Yogyakarta

Ala, Andre Bayo. 1981. "Kemiskinan dan Strategi Memerangi Kemiskinan". Liberty: Yogyakarta.

Aminatun, Siti dan Tri Laksmi Udiati. 2003. "Mewaspadai Kemiskinan sebagai Salah satu Faktor Potensial Tindak Kekerasan". Media Informasi Penelitian No.173 tahun ke 27 hal 63-77.

Darwin, Muhadjir. 2005. "Memanusiakan Rakyat. Penanggulangan Kemiskinan Sebagai Arus Utama Pembangunan”. Benang Merah: Yogyakarta.

Djamaluddin, Ancok. 1995. "Pemanfaatan Organisasi Lokal" dalam Kemiskinan dan Kesenjangan di Indonesia ed Amien Rais. Aditya Media : Yogyakarta.

Effendi, Tadjuddin Noer. 1992. "Tinjauan Kritis Konsep Kebudayaan Kemiskinan" dalam Dinamika Ekonomi dan IPTEK dalam Pembangunan. PT Tiara Wacana: Yogyakarta.

Geertz, Clifford. 1981."Involusi Pertanian".

1996 "Urbanisasi dan Kemiskinan di Dunia Ketiga". PT Tiara Wacana: : Yogyakarta

Kleiden, Ignas. 1987 "Masalah Kemiskinan Sosial-Budaya di Indonesia". Prisma 16 no 8 (1987): 15-28

Lewis, Oscar. 1988 "Kisah Lima Keluarga" telaah-telaah kasus Orang Meksiko dalam Kebudayaan Kemiskinan. Yayasan Obor Indonesia: Jakarta

Marzali, Amri. 2003 "Strategi Peisan Cikalong dalam Menghadapi Kemiskinan". Yayasan Obor Indonesia : Jakarta

Nugroho, Heru. 1995. "Kemiskinan, Ketimpangan, dan Pemberdayaan" dalam Kemiskinan dan Kesenjangan di Indonesia ed Amien Rais. Aditya Media : Yogyakarta.

Sairin, Sjafri. 1997. "Upaya Memerangi Kemiskinan dalam Pikiran-Pikiran Alternatif Pengentasan Kemiskinan dalam Dinamika Masyarakat Menjelang Abad 21". Pusat Studi Penelitian Kependudukan Universitas Gadjah Mada

Sukamdi dan Setiadi. 2003. "State-Created Socio-Cultural Poverty: Lesson from Some Micro Studies" dalam The Indonesian Crisis, A Human Development Perspective ed Aris Ananta. Institute of Southeast Asian Studies: Singapore

Suparlan, Parsudi. 1984. "Kemiskinan di Perkotaan" bacaan untuk Antropologi Perkotaan. Yayasan Obor Indonesia : Jakarta

Usman, Sunyoto. 2004 "Pembangunan dan Pemberdayaan Masyarakat". Pustaka Pelajar: Yogyakarta. 


\section{Sumber Internet}

Abdullah, Irwan dalam "Tantangan Pembangunan Ekonomi dan Transformasi Sosial : Suatu Pendekatan Budaya”, Humaniora, vol xiv.No 3/2002

Ali Djayono "Peran Sektor Kehutanan dalam Penanggulangan Kemiskinan".

Majalah Kehutanan Gambaran Kemiskinan dan Action Plan Penanganannya

(Makmun) dalam Kajian Ekonomi dan Keuangan, Vol.7, No 2 Juni 2003

Indonesia Edisi II Tahun 2006.htm

"Ideologi Punya Kaki dan Tangan" Bali Post.htm 18 Juli 2004

Memahami Kemiskinan dalam Ragnar Nurkse,1953 Pembangunan Daerah dan Pemberdayaan Masyarakat dalam MEMAHAMI KEMISKINAN.htm

PTS Publications \& Distributors Sdn Bhd - Sumbangan Al-Attas kepada kajian Asia Tenggara.htm

http://www.utusan.com.my/utusan/tools/date_search.asp 